\title{
Analysis of Solidarity to Human Rights as Reflected in the Song Lyrics titled "Hear Your Call" by Sami Yusuf
}

\author{
Aa Qonaatun \\ Banten Jaya University \\ Serang, Indonesia \\ aaqonaatun@unbaja.ac.id
}

\begin{abstract}
This study try to analyze solidarity to human rights as reflected in the lyrics of the song entitled "Hear Your Call" by Sami Yusuf by using a sociological approach of literature. This study is a qualitative using content analysis method. The technique of study and data analysis is content analysis by identifying and interpreting the lyrics in the song, and then recognizes it as the data of study. Based on the analysis and discussion of song lyrics, it is concluded that there are 6 lines of song lyrics that contain of solidarity to human rights in the social, economic and cultural fields. Based on the sociology of the reader, it is concluded that the song is aimed to the reader or listener of the song, the lyrics contain the meaning and messages that want to influence their point of view and response after reading or listening to the song, and also expected to provide influence on the social conditions of victims in the flood disaster in Pakistan. The result of this study can be used as learning material in providing model of communicative English teaching through songs and also to support teaching materials in English Literature subject.
\end{abstract}

Keywords: solidarity, human right, song lyrics, sociology of literature

\section{INTRODUCTION}

Solidarity is an important principle to build social life, because of solidarity; people can realize many things together. According Wardhaugh and Fuller (2015: 9) solidarity refers to motivation that influences individuals to act together and feel the bonds that affect their social actions. Thus the concept of solidarity is related to the formation of identity and the formation of groups. Therefore, so that solidarity can be realized by all parties, then everyone should have to complement each other, strengthen each other, care for each other and help each other. As performed by Sami Yusuf, he is a singer and songwriter who created songs that reflect solidarity. The solidarity contained in the song titled Hear Your Call is solidarity to human rights. Sami Yusuf composed the song because it discussed the floods experienced by Pakistanis in 2010.

Based on the album's information on the official Sami Yusuf website; On August $26^{\text {th }}, 2010$, Sami Yusuf released a charity single entitled Hear Your Call to raise funds for flood victims in 
Pakistan. Further more, on July $11^{\text {th }}$, 2011, he released a single titled Never Forget to remind people around the world, especially Muslims and listeners of his songs, so as not to forget the genocide that occurred in Bosnia about 16 years ago from the time of the song Never Forget was released. Furthermore, on August $8^{\text {th }}$, 2013, Sami Yusuf released another charity single, entitled Silent Words for Syria and its people.

A song can be used as a medium to provide information and perspectives about social problems that occur in society and even in the world, because song lyrics contain deep meaning and messages. Through a song, the song writer can convey his thoughts and perspectives can influence the mindset of the listener with the aim of creating a certain atmosphere and imagination to the listener.

As research in the Journal of Arts and Education Volume 15 Number 1 by Ekaningrum (2015: 9) states that song listeners not only enjoy musical tunes, but also lyrics. The lyrics represent the songwriter's mind and help the listeners understand what is on the songwriter's mind. In addition, listeners sometimes prefer lyrics to songs. Therefore, lyrics can also play a role in determining whether a song will be liked or not. Furthermore, in the Journal of Literature, Language and Culture Volume 3 Number 1 by Shomad (2014: 2) explains that lyrics are the media used to convey messages from songwriter to listeners. Therefore, through song lyrics, songwriters convey messages in writing with beautiful words that have profound meanings and touch the feelings to be sung, which can influence the listener's mindset.

Based on the explanation above, the writer is interested in analyzing solidarity to human rights as reflected in the lyrics of the song Hear Your Call by Sami Yusuf by using a sociological approach of literature. Therefore it is important for us fellow humans to work together in building solidarity, especially solidarity to human rights. In addition, teachers are expected to instill and teach students the meaning of solidarity, so that future generations can be more concerned and sensitive to social problems that occur, both in their mindsets and behavior.

In addition, from this study it can be learned that communicative English can be applied through a song. As 
explained in the background above, that through the song, songwriters can convey a message to the listener or reader, then they respond by understanding every message contained in the lyrics of the song, so they can behave carefully, sympathize, get angry, be happy and even cry. Those feelings are the communication that a songwriter wants to build to the listeners or readers. Learning communicative English through songs is also good for teachers to teach students, because sometimes students are more interested in learning through audio and visual media rather than reading textbooks or reading materials on the board. Therefore, before

\section{METHOD}

The approach used in this research is a qualitative approach using content analysis methods. A qualitative approach is expected to be able to produce in-depth descriptions of speech, writing, or behavior that can be observed from an individual, group, community, and/or particular organization in a particular context setting which is studied from a complete perspective. In this study the writer used content analysis to analyze data in the form of song lyrics to determine solidarity with a teacher can teach communicative English through songs to students, he needs to understand how the songwriter conveys messages through songs with a specific purpose. So that the song can touch the feelings of students and also they can understand the message conveyed, and in the end their mindset, point of view, and attitude are awakened after listening or reading the song. Through the results of this study, in addition to teachers being able to teach communicative English through songs, lecturers can also use the results of this study to support the teaching materials in English Literature subject, especially English Poetry.

human rights as reflected in the lyrics of the song Hear your call by Sami Yusuf.

In this study, the main data source is the song lyrics titled Hear Your Call by Sami Yusuf. The writer takes secondary data sources from various sources as references, such as songwriter biographies and album descriptions from official websites, opinions and theories by experts from articles, journals, books and e-books. The writer takes secondary sources to strengthen the results of the analysis of the primary sources. In analyzing the data, the writer uses 
Volume 3 No. 1, February 2020

P-ISSN 2623-0062

Universitas Banten Jaya

E-ISSN 2622-9056

descriptive qualitative analysis of the

contents. The steps of data analysis in

this study are as follows: review the data

that has been collected, analyze the

\section{DISCUSSION}

Before the song was created by Sami Yusuf, there was a natural disaster that occurred in Pakistan in 2010, the biggest flood disaster in the country's history which caused the Indus river to overflow. The disaster affected around 20 million people and killed at least 1,600 more people. In addition to many fatalities, many victims must be separated from their families, many children are separated from their parents. In addition, Pakistan's flood disaster also caused children to be infected by various diseases, lack of clean water, clothing and also food.

Therefore, Sami Yusuf composed a song titled Hear Your Call to reflect his sympathy and concern for the flood victims in Pakistan. Furthermore, on August 26th, 2010, he released a charity single of a song to raise funds for flood victims in Pakistan. In addition, based on the title of the song Hear Your Call, Sami Yusuf really wants people all over the world, especially the listeners of his songs, as fellow human beings to

meaning and message contained in each song's lyrics, analyze song lyrics using a sociological approach to literature and obtaining study results.

participate in helping victims of the Pakistan floods. In addition, it is based on human rights that there is no discrimination in helping. Obligation as a fellow human being is to help each other, especially in this case helping each other to maintain life.

The following are the lyrics of the song Hear Your Call by Sami Yusuf

\section{VERSE 1}

Don't despair, don't lose hope

Hold on to that rope

Don't let go, don't let go

I hear your call

VERSE 2

Though you feel so cold

Abandoned and alone

But don't let go, don't let go

I hear your call

CHORUS

Give me your hand my brother

I will not let you go

Please don't look back my sister 
Volume 3 No. 1, February 2020

Universitas Banten Jaya

I swear I hear your call

Give me your hand my brother

I will not let you fall

I hear your call

Please don't look back my sister

Cause I swear I hear your call

VERSE 3

Little boy ask away

$U R D U$

UMMEDON KO NA TODO

HAATH MERA THAAM LO

TANHA NAHI SAMJHO TUM

MERE APNE TUM HO...

(We are a family)

"Where are the streets I used play to?"

But don't let go, don't let go

I hear your call

Don't you know we're one

When you hurt I hurt

Don't let go, don't let go

\section{CHORUS}

Give me your hand my brother

I will not let you fall

So don't look back my sister

Cause I swear I hear your call

Before analyzing the meaning of solidarity to human rights from the lyrics of the song Hear Your Call, the writer will explain that the song Hear Your Call consists of 32 lines of lyrics, 4 verses including 1 verse using Urdu and 2 choruses. In this study the writer analyzed each verse to find out the meaning and message contained in the song's lyrics.

Analysis and discussion of song lyrics by the writer are as follows;

Don't despair, don't lose hope

Hold on to that rope

Don't let go, don't let go

I hear your call

As stated above, Hear Your Call is a humanitarian theme song that was composed based on the care and sympathy of songwriter for the victims of the Pakistan flood in 2010. In the first line "Don't despair, don't lose hope", Pakistani flood victims are described as feeling hopeless because the flood disaster experienced by them is the worst natural disaster that has strucked Pakistan since the earthquake in 2005, besides this disaster struck during a war between the government Pakistan and the Taliban, as well as in Pakistan's difficult national economic times. (https://www.bbc.com/indonesia/dunia/2 
010/07/100731_floodpakistan). But in the second and third lines "Hold on to that rope", the songwriter conveys the message to the victims to always have hope, not despair of the disaster that happened. Sami Yusuf as songwriter convinced the victims through his lyrics "I heard your call", that he knew their suffering, he knew they needed to be saved, needed food, needed life force and needed many things to sustain their lives and as fellow man he really cares about and will try to help them.

Though you feel so cold

Abandoned and alone

But don't let go, don't let go

I hear your call

The lyrics in the fifth line "Though you feel so cold" describe the condition of Pakistani flood victims feeling cold because their homes have been destroyed by the flood. According to information Minister Mian Iftikar Hussain, nearly 400 thousand people were displaced within two days (BBC Indonesia, 30 July 2010). Then in the next line "Abandoned and alone", Pakistan flood victims also feel that they are left behind and feel alone because they think no one will care about the disaster that struck them. Their situation was very bad and frustrating considering that the Pakistani government at that time was considered too slow in responding to the disaster, where flood victims were mainly dependent on military aid and foreign humanitarian organizations. In addition, only a quarter of the total promised aid of US \$ 459 million received by refugees. This little amount is in sharp contrast to the amount of military aid in extinguish militant last year, which reached around 1 billion US dollars (Republika, August 17, 2010, 20.04 WIB). But the songwriter gave confirmation through the lyrics of his song, "But don't let go, don't let go" "I hear your call" really help them from their worst conditions.

Give me your hand my brother

I will not let you go

Please don't look back my sister

I swear I hear your call

Give me your hand my brother

I will not let you fall

Please don't look back my sister

Cause I swear I hear your call

In the next line "Give me your hand my brother", the songwriter tells the victims to receive aid from any party, always believe that there are still many good 
people who will help them with sincerity as fellow human beings. As reported in the online media detikNews and the Indonesian Embassy in Islamabad that many countries are concerned and provide assistance, including the US government donating the most funds, which is around US \$ 70 million. The US has also deployed its military helicopters to rescue people trapped by flooding and reduce food and drinking water. Other big donations came from the United Kingdom, which provided around US \$ 32 million, Germany at US \$ 13 million, Australia at US \$ 10 million, Kuwait at US \$ 5 million, Japan at US \$ 3.5 million and Norway at US \$ 3.5 million. \$ 3.3 million and likewise with Indonesia, which donated US \$ 1 million, besides providing assistance such as family tents, velbeth, generators, blankets, gloves, 4.5 tons of prepared fast food, medicines and complementary foods for baby's meal. Reiterated in the next line "I will not let you go", the songwriter conveys the message that as a fellow human being he will try his best to help their suffering. Then in the next line, "Please don't look back my sister", the songwriter wants to convey a message to the flood victims of Pakistan (especially women and children) so they do not always remember the disasters and do not feel pessimistic, because women and children are usually prone to illness, take a rest is not comfort (not as free as men, because women have lots of privacy), get menstruation in disaster conditions and women's limitations in doing many other things. Then in the next line the lyrics "I swear I hear your call" which is the meaning of this songwriter wants to reassure and reaffirm that as humans he really cares and will help them by releasing this song so that listeners are compelled to give assistance which will then be donated to Pakistani flood victims.

\section{Little boy ask away}

"Where are the streets I used play to?"

But don't let go, don't let go

I hear your call

Don't you know we're one

When you hurt I hurt

Don't let go, don't let go

I hear your call

Furthermore, in the lyrics Sami Yusuf wrote "Little boy ask away" "Where are the streets I used play to?" 
these lyrics explain that the victims of the flood are not only adults, but also children, many of children are separated from parents and become orphans, besides that children are very vulnerable to disease and also need adequate nutrition. In fact there is no longer a comfortable and appropriate place for children to grow and play because it has been destroyed and lost by the flood. This was also revealed by the Pakistani Ambassador to Indonesia, Sanaullah, who estimated that at least 300 thousand pregnant women and 3.2 million children were suffering from the flash floods that struck Pakistan (DetikNews, Sunday, August 22, 2010, 23:55 WIB). Then continued with the next lyrics, "But don't let go, don't let go" "I hear your call", the songwriter reiterates for the umpteenth time, even though the situation of flood victims including children is very concerned, but he wants to continue to encourage that they should not give up and must continue to rise from adversity. The songwriter also says "Don't you know we're one" "When you hurt I hurt", here Sami Yusuf as songwriter wants convey a message to the flood victims of Pakistan through the lyrics that they are brothers, besides that
Pakistan is a country that is predominantly Muslim, so between songwriters and residents of these countries certainly have close ties and brotherly/ human relations. So the songwriter supposes that if they feel pain, then he will also feel the same thing, as stated in a hadith which states that "a Muslim is a brother to other Muslims".

\section{UMMEDON KO NA TODO}

(Do not lose hope)

HAATH MERA THAAM LO

(Hold my hand)

TANHA NAHI SAMJHO TUM

(Do not consider yourself alone)

MERE APNE TUM HO...

(We are a family)

UMMEDON KO NA TODO

(Do not lose hope)

HAATH MERA THAAM LO

(Hold my hand)

TANHA NAHI SAMJHO TUM

(Do not consider yourself alone)

MERE APNE TUM HO...

(We are a family)

Then, in the next lyrics, Sami Yusuf as the songwriter writes the lyrics in Urdu, which language is first language of the State of Pakistan itself, the meaning contained in these lyrics 
Volume 3 No. 1, February 2020

P-ISSN 2623-0062

Universitas Banten Jaya

E-ISSN 2622-9056

actually has the same essence as the

In the last, in the twenty-eighth

previous lyrics, the writer wants to give

encouragement and motivated the

Pakistani flood victims to remain strong

in the face of all the disasters that had occurred, and he himself had promised that he would try to help them, because they were considered part of the songwriter (Sami Yusuf). The difference with the previous lyrics is that the lyrics in the twenty-fifth to the twenty-eighth line use Urdu, with the intention that Pakistanis can understand deeply the content and purpose of this song. In addition, Urdu is one of language that is widely used in the field of literature, Lots of literary works written in this language and translated in the literary field, both in the South Asian region. The poetry uttering Urdu was first published by Masud Saad Salman in 1066 AD. Literary genre (prose and poetry) in Urdu are abundant.

https://id.wikipedia.org/wiki/Language_Urdu

Give me your hand my brother

I will not let you fall

So don't look back my sister

Cause I swear I hear your call 
obtaining a decent standard of living, including food, clothing and shelter, because of the flood that struck them, they lost everything including property, so they really need help, need clean water, shelter, food and clothing.

2. Song lyrics on line 17: "Little boy ask away" and song lyrics on line 18: "Where are the streets? I used play to?", The meaning and message in this lyrics are interrelated. The meaning and message in the lyrics reflect the songwriter's solidarity with children who are victims of the Pakistan floods that he is worried about their fate and growth. This means that this lyrics reflects the solidarity with human rights in the rights to health and the right to education, because of the floods that struck them, children lose their parents and become orphans and there is no comfortable and suitable place for them to grow and play, they cannot get proper education and easily infected by life-threatening diseases. Therefore, they really need help and need to be saved because they have the right to get

proper education and health.

As explained above, there are song lyrics in Hear Your Call song that reflect solidarity with human rights in the right to an adequate standard of living, including food, clothing and shelter, as well as the right to health and education. Not only that, it has also been explained that Sami Yusuf composed this song with a special purpose to reflect his sympathy and concern for the flood victims of Pakistan so he released a charity single with this song to raise funds to help them. In doing so, he made an effort through his work to exert influence on the social conditions of Pakistani flood victims. By the charitable funds obtained from the single, at least it can help fulfill the primary needs of the flood victims of Pakistan.

In addition, from these song lyrics, listeners and readers can find out how much their help is needed by Pakistan flood victims. Furthermore, because of this song, listeners and readers can realize the importance of solidarity to human rights in the fields of economic, social and cultural rights so 
songwriter's solidarity with the floods of victims of Pakistan's floods.

In fact, the charity single of Sami Yusuf through this song is selling well in the entertainment industry, this shows that there are many listeners and readers who understand the noble intentions and purpose of Sami Yusuf to release this song, and indirectly they also contribute to help the flood victims of Pakistan.

\section{CONCLUSION}

Based on the analysis and discussion of the lyrics of the song Hear Your Call by Sami Yusuf that has been presented in the previous section, the writer can provide the following conclusions.

First, based on the results of 32 lines song lyrics analysis and Hear Your Call song discussion, it was concluded that there are 6 lines of lyrics in this song that focus on solidarity with human rights in the field of economic, social and cultural rights consisting of 4 song lyrics that reflect solidarity on human rights in the right to an adequate standard of living, including the right to obtain food, clothing and shelter, because the meaning and message in the 4 lines of the song's lyrics reflect the 
Volume 3 No. 1, February 2020

P-ISSN 2623-0062

Universitas Banten Jaya

E-ISSN 2622-9056

titled Hear Your Call by Sami Yusuf are aimed to readers and listeners that contain meaning and messages that give influence to their perspectives and attitudes after reading or listening to the

\section{REFERENCE}

Ekaningrum, Prastiana. (2015). The Analysis of Meanings and Forms in The A.T Mahmud's Song Lyrics. Harmonia: Journal of Arts Research and Education. Vol. 15, No. 1, P.9-15. State University of Semarang. Retrieved from: http://journal.unnes.ac.id/nju/index.ph p/harmonia

Shomad, Abdus. (2014). Analysis of Metaphors in Term of Slavery Resistance as Reflected in Bob Marley's Songs Lyrics; Redemption Song and Buffalo Soldier. Rainbow: Journal of Literature, Linguistics and Cultural Studies. Vol. 3, No. 1, P.1-9. State University of Semarang. Retrieved from:

$<$ http://journal.unnes.ac.id/sju/index.ph p/rainbow >

Wardhaugh, Ronald and Janet M. Fuller. (2015). An Introduction to Sociolinguistics. 7th ed. USA: Wiley Blackwell.

BBC News Indonesia.(2010). Korban Tewas Banjir Pakistan 800 Orang. Accessed on 17th January 2020 from https://www.bbc.com/indonesia/dunia/ 2010/07/100731_floodpakistan.

Republika. (2010). Pengungsi Pakistan Mulai Frustasi. Accessed on 17th January 2020 from https://internasional.republika.co.id/ber ita/internasional/internasional/130549/ breaking- 
Volume 3 No. 1, February 2020

P-ISSN 2623-0062

Universitas Banten Jaya

E-ISSN 2622-9056 